\title{
MADREPORA CARDUUS.
}

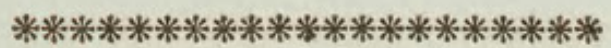

CHARACTER GENERICUS.

Animal Medusa.

Corallium cavitatibus lamelloso-flexuosis.

$$
\text { Lin. Syst. Nat. p. } 1272 .
$$

CHARACTER SPECIFICUS, छ'C.

MADREPORA dichotoma, ramis sulcato-muricatis, stellis simplicibus regularibus, lamellis serrato-dentatis.

Soland et Ellis Zooph. p. 153. t. 35 ,

. MADREPORA lacera.

Pall. Elench. Zooph. 298.

Super rupes Maris Indici crescit Madrepora Carduus. Veram ejus magnitudinem ostendit tabula. 



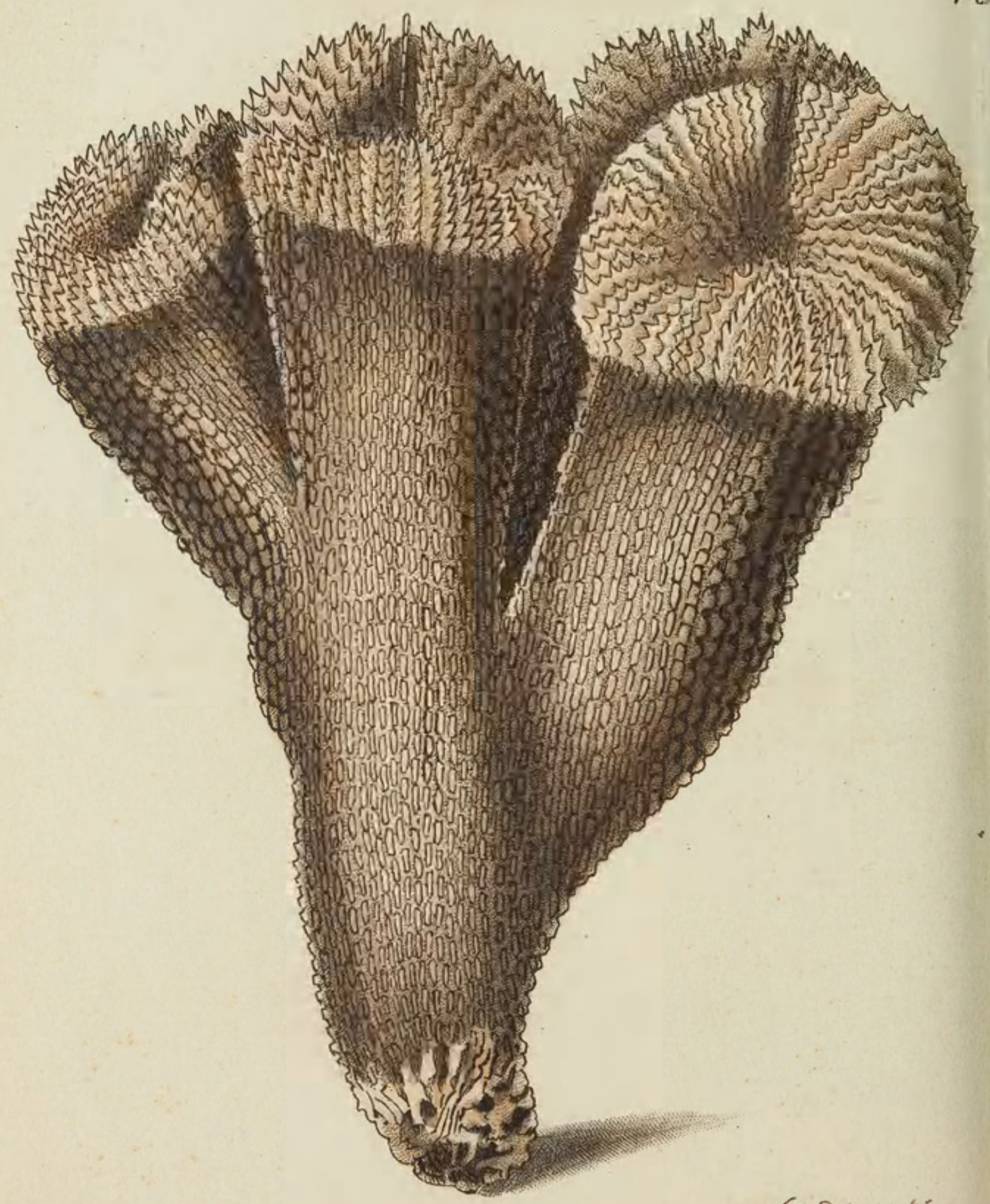

2aNoser Del ot dulpt 


\section{THE \\ THISTLE MADREPORE.}

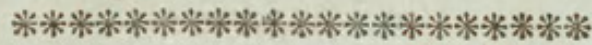

GENERIC CHARACTER.

Animal allied to a Medusa.

Coral marked with lamellar star-shaped cavities.

SPECIFIC CHARACTER, छ\%.

Dichotomous MADREPORE, with furrowed, muricated branches, simple, regular stars, and tooth-serrated lamelix. MADREPORA CARDUUS.

Soland ङ Ellis Zooph. p. 153. pl. 35.

The Thistle Madrepore is found adhering to rocks in the Indian ocean, and is represented in its natural size on the annexed plate. 


\section{$2 \mathrm{BHL}$ Biodiversity Heritage Library}

Shaw, George. 1806. "The Thistle Madrepore, Madrepora carduus [PI. 703]." The Naturalist's Miscellany 17(CCII), https://doi.org/10.5962/p.311140.

View This Item Online: https://www.biodiversitylibrary.org/item/281954

DOI: https://doi.org/10.5962/p.311140

Permalink: https://www.biodiversitylibrary.org/partpdf/311140

\section{Holding Institution}

Museums Victoria

\section{Sponsored by}

Atlas of Living Australia

\section{Copyright \& Reuse}

Copyright Status: Public domain. The BHL considers that this work is no longer under copyright protection.

This document was created from content at the Biodiversity Heritage Library, the world's largest open access digital library for biodiversity literature and archives. Visit BHL at https://www.biodiversitylibrary.org. 